\title{
The happiness of undergraduate students at one university in the United Arab Emirates
}

\author{
Ibrahim, Ali $₫$ \\ United Arab Emirates University, United Arab Emirates (ali_saidebrahim@uaeu.ac.ae)
}

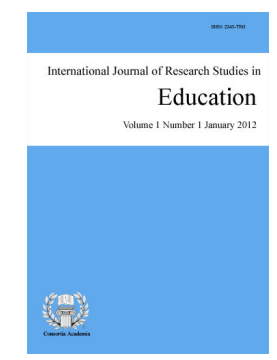

ISSN: 2243-7703 Online ISSN: 2243-7711

OPEN ACCESS

\section{Abstract}

Numerous studies show that happy individuals are successful across multiple life domains including marriage, friendship, income, work performance, and health. Research indicates also that one impediment to increasing the happiness of society is a failure to understand that happiness can be measured, understood, and enhanced. This study explores college students' happiness over seven life domains: self, educational institution, family, social relations with friends, living environment, freedom, and future financial security. The purposes of the study are to determine the degree of students' happiness and identify which life domains have the greatest or least influence on their well-being. Participants are 654 male and female students at one federal university in the UAE. The study used the Multidimensional Student Life Satisfaction Scale, which assessed the first five domains, and a researcher-developed survey for two additional domains of the freedom students have, and future financial security. The study found that students were mostly happy. However, they showed moderate happiness with their educational institution. Happiness was significantly greater for female students than for male students throughout all domains. Finally, Emirati students showed more happiness than non-Emirati Arab students over five domains: family, self, living environment, the freedom they have, and future career security. The findings help policy makers reach informed decisions regarding domains in need of attention and suggest ways in which happiness can be enhanced.

Keywords: student happiness; student well-being; college students; university education; UAE 


\section{The happiness of undergraduate students at one university in the United Arab Emirates}

\section{Introduction}

The UAE national agenda aims for the UAE "to be the happiest of all nations so that its citizens feel proud to belong to the UAE" (UAE National Agenda, 2014). To help achieve this aim, HH the Prime Minister appointed a Minister of State for Happiness in February 2016 and stated that "We want a government that works on building the skills of its people, aside from providing services ... a government focused on putting the happiness of citizens at the forefront of its priorities" (Khaishgi, 2016, para 6). Miss Ohood Al Roumi, the Minister for Happiness, considers "Happiness... a serious job for governments" and views it as part of a "holistic approach for development” (Khaishgi, 2016, para 2).

The happiness of college students is an important issue. College years are formative for students and can lead to lifestyles that endure for the years ahead. Astin (1997) argued that college years have strong effects on students and that the experiences students live through help them develop a greater sense of interpersonal and intellectual competence and a greater commitment to developing a meaningful philosophy of life. Further, he states that students are the most important influence on other students' development, and that students' values, beliefs and aspirations typically change in the direction of the dominant values, beliefs and aspirations of other students. In addition, college students experience stress from a variety of sources including the increased workload, and new responsibilities (Ross, 1999) as well as family, social, and daily hassle (Brougham, Zail, Medonza, \& Miller, 2009). Therefore, it is essential to help students develop in positive directions, appreciate their own worth, and cope with stress factors.

This study explores happiness among students at one UAE federal university over different life domains. It identifies students' well-being status and determines in which life domains they appear to be least and most happy. The results are significant not only as they provide policy makers and the newly established ministry of happiness with a description of the status of university students' well-being, but also by highlighting areas or domains in need of their attention. The results can be used as a starting point for university policies which aim to raise the level of happiness among students.

\subsection{Research questions}

This study is guided by the following research questions:

$>\quad$ To what extent are university students happy within different life domains?

$>\quad$ What are the domains within which students were most and least happy?

$>\quad$ What are the significant differences in the happiness of students based on their gender and nationality?

\section{Literature Review}

An important theme in the study of happiness is whether scientific research can lead to enhanced happiness at the individual and societal levels. Lykken (1999) and Lyubomirsky, Sheldon, and Schkade (2005) described happiness as the sum of an individual's set happiness point $(\mathrm{S})$, the individual's circumstances $(\mathrm{C})$, and the factors which are under an individual's control $(\mathrm{V})$. Thus, happiness $(\mathrm{H})=\mathrm{S}+\mathrm{C}+\mathrm{V}$. Although they argued that it is difficult to change an individual's happiness set point and life circumstances, they nonetheless concluded that happiness can be enhanced by addressing the factors under the individual's control. In line with this thesis, Norrish and Vella-Brodrick (2007) set out to prove that the scientific study of happiness is a worthy pursuit. They deconstructed the view that the study of happiness is not useful and asserted that happiness is an important 
human condition that deserves scientific recognition. The authors noted two main challenges in investigating happiness, however. The first was that happiness is typically conceptualized from a set point theory perspective, according to which, increasing happiness levels is difficult due to genetic limitations. The second challenge was whether the measurement of happiness could occur with scientific rigor. They found that improvements in physical, psychological and social health could indeed have significant influence on happiness. The authors discussed ways to increase happiness, including enhancing the factors which are under the individual's control, and fostering kindness and gratitude. These suggestions were confirmed by research which demonstrated that kind and grateful people appear to be happier than less grateful and less kind people.

Cummins, Lau, Mellor, and Stokes (2008) discussed policies to enhance happiness at the societal level. The authors asserted that happiness is a measurable item within the framework of science, and that policy makers have failed to realize that enhancing the happiness of citizens enhances not only their functioning as individuals but also the population as a whole. The authors contended that one role of governments should be to distribute resources fairly so that the population's well-being could be enhanced. Specifically, governments should be concerned with effective management of the economy, ensuring the safety of citizens, increasing access to paid employment, and distributing services and financial resources to needy people. These strategies, they argued, would enhance the happiness, productivity and livability of society as a whole.

Another theme in the study of happiness relates to the conceptual constructs and the tools used to study happiness. For example, Kashdan (2004) assessed the concept of Subjective Well-Being (SWB) as introduced by the Oxford Happiness Questionnaire (OHQ). Happiness or subjective well-being, as it is used interchangeably in literature, is the cognitive and affective evaluation of one's own life (Diener, 1994). Kashdan noted the conceptual overlap between the OHQ and other constructs. A key argument made by the author was that the item content of the OHQ fails to differentiate the assessment of SWB from the predictors, correlates and consequences of SWB. As such, the OHQ appears to invite nonrandom error into the study of SWB. He further stated that there are cross-national and cross-cultural differences to be considered in assessing happiness. $\mathrm{He}$ argued that high SWB comprises the following three factors: 1) frequent and intense positive affective states, 2) the relative absence of anxiety and depression, and 3) life satisfaction. The author also noted on several occasions that more studies have focused on the negative, happiness-inhibiting aspects than positive, happiness-promoting factors in their research. The article concludes with an appeal for the use of more stringent conceptual and analytic approaches to the study of happiness.

Cheng and Furnham (2002) examined the extent to which peer relations, self-confidence and school performance correlate with self-rated happiness and loneliness. The authors asserted that depression is roughly synonymous with unhappiness. Some key points noted are the different types of loneliness, emotional and social. Emotional loneliness has to do with the quality of close interactions whereas social loneliness revolves around the 'network' size. The study found that friendship, extraversion and neuroticism were predictors of happiness while self-confidence and psychoticism were predictors of loneliness. However, the absence of certain factors that predict happiness do not imply the likelihood of loneliness and vice versa. Gender difference is also found to be a significant factor in leading to loneliness, which would in turn affect happiness. As found in previous studies, girls in this study were found to be slightly less lonely than boys. However, the more striking difference between girls and boys is in the quality of friendship in which girls are doing markedly better than boys possibly due to their higher expectations from friendship as well as their superior friend-making skills. Moreover, the dominance of one nationality in the campus could also lead to loneliness for students of minority national or cultural groups.

Chow (2005) observed that strengthening of students' life satisfaction has been considered an important mission of education in Canada and argued that happiness is affected by various constructs such as age, stress, physical health, parenting style, lifestyle and personality. The results of his study demonstrated that Canadian university students were extremely satisfied with their lives and especially in their relationships with parents, siblings, living environment, and close friends and also that students with higher socioeconomic status scored 
higher on exams and held higher GPAs. Therefore, they were more satisfied with their academic experience, self-esteem, living conditions, and they expressed a noticeably higher level of satisfaction with life.

Dean and Gibbs (2015) attempted to challenge deficiencies in the education systems with respect to the pursuit of happiness and satisfaction among university students. They explored happiness not as a short-term period of joy and ecstatic eruption of pleasure, but as a long-term course of life. Specifically, their study investigated the purpose of higher education and the transformative experiences through which students come to terms with a way of being, matching their potentiality with their agency and leading to long-term, profound happiness. They suggested that the idea of quality in higher education should extend beyond satisfaction and developed a notion of student happiness as one of the attributes by which educational provision should be judged. They argued that identifying profound happiness should become a goal for student development. Consideration of profound happiness, they argued, ought to help to focus the university's mission. To guide universities in helping students reach profound happiness, the authors called on universities to increase student engagement, as they found student engagement to be a significant factor in profound happiness, especially among female students.

Michalos (2008) investigated whether education has an influence on happiness and if so, how and to what degree. He observed that answers to these questions would depend on how one defines and operationalizes the terms education, influence, and happiness, and suggested that robust definitions of these terms be established before governments start to think about what public policies to adopt to enhance happiness. He portrayed a happy person as someone who is likely to have no fear, tension, guilt, hostility or anger and who possesses a high degree of energy, vitality and activity. He argued that educational attainment is positively associated with both health status and healthy lifestyle. In conclusion, he views humans as complex organisms, and as such, an adequate construction of the idea of their well-being must also be complex.

Flynn and McLeod (2015) examined the relationship between happiness and six other life domains: academic success, financial security, familial support, living environment, self-image and social relations. The aim of their study was to determine which life domain had the greatest influence on student happiness, and their results showed that self-esteem, academic success and financial security, respectively, explained most of the variance in student happiness. Their analysis showed no difference in happiness correlated to gender, a finding consistent with previous studies such as that of Cheng and Furnham (2002). However, it is important to note that the sample of their study, while representative, had a gender imbalance (e.g., $81 \%$ female, 19\% male) and may not be generalizable.

\section{Methodology}

This study is set to explore the perceptions of a large sample of university students regarding the different domains connected to their happiness, which domains they are most and least happy with, and whether differences exist in their happiness based on their gender and nationality. Therefore, the study used a quantitative research methodology to achieve those objectives.

\subsection{Instruments}

To explore the perceptions of university students regarding the different domains connected to their happiness, I used the Multidimensional Student Life Satisfaction Scale (MSLSS) (Huebner, 1994). The MSLSS is a scale measuring satisfaction with self-image, academic performance/success, family support, social relations, and the living environment. The MSLSS is in the public domain and therefore it may be used without permission from the author. In addition, I developed and included two more domains to those used in the original MSLSS: level of freedom students have, and their future financial security. These two domains were added based on recommendations made by Undergraduate Student Assistants (USAs) in my department. During focus group meetings, two female USAs expressed concerns about the level of independence or the freedom they enjoyed in 
The happiness of undergraduate students at one university in the United Arab Emirates

their families and at the educational institution. The two male USAs, being non-Emirati students, were especially concerned about their future employment. The decision was made to add both domains to the questionnaire.

In its first version, the questionnaire was composed of 55 items; 40 for the MSLSS and 15 for the newly added domains. Students' chose from six responses ranging from "strongly disagree" $=1$ to "strongly agree" $=6$. After collecting the data, it was found that three newly added sentences caused alpha coefficient to decrease. These sentences were "I feel traditions and customs limit me," "I feel I have equal chances as anyone else in class," which were in the freedom domain, and "I feel afraid of the future" which was in the future career domain. These three sentences were subsequently deleted from the questionnaire, leaving the total number of final questionnaire items at 52. In addition to these 52 questionnaire items, a short version of the questionnaire with one question from each domain was used and completed by the same sample of students. Students were asked to rate their level of happiness on different domains and on life in general along a continuum represented by six choices ranging from "feeling terrible" $=1$, "mostly unhappy" $=2$, "sometimes unhappy" $=3$, "sometimes happy" = 4, "mostly happy" = 5, and "feeling delighted" = 6. The last section in the questionnaire covered demographic information, and prompted students to complete five questions on their gender, age, college, living on or off-campus, and nationality.

\subsection{Validity and Reliability}

Internal consistency of the MSLSS has been reported in various publications and the test-retest coefficients mostly fall in the 0.70-0.90 range (Huebner, 2001). Factorial analyses have also supported the validity of the questionnaire dimensions (Huebner, 2001). For the two newly added domains to the MSLSS, validity was insured by a jury of four scholars who strongly agreed on the sentences in each dimension. In addition, in the domain of future career security, the sentences were drawn from the Oxford Happiness Questionnaire, a widely used and validated tool. After data collection, the scale was re-analyzed for reliability. Table 1 presents alpha coefficients for this study.

\section{Table 1}

Alpha coefficients for the various domains in the questionnaires

\begin{tabular}{lcc}
\hline \multicolumn{1}{c}{ Domain } & Number of items & Alpha \\
\hline Family & 7 & .89 \\
Friends & 9 & .83 \\
University & 8 & .80 \\
Living environment & 9 & .74 \\
Self & 7 & .78 \\
Freedom & 6 & .64 \\
Future career & 6 & .66 \\
MSLSS domains & 40 & .89 \\
New domains & 12 & .76 \\
Short version of Q & 8 & .85 \\
All domains & 52 & .92 \\
\hline
\end{tabular}

As can be noted, the questionnaire has a very high reliability of .92. The alpha for the five SMLSS domains ranged between .74 and .89 and in total their alpha was .89. The two newly added domains came at an acceptable alpha of .64 and .66 and their combined alpha was .76. The alpha for the short version of the questionnaire was .85 .

\subsection{Sample}

The sample for this study was composed of 654 students who registered for summer courses at one UAE federal university. This sample was drawn from a population of 2109 students: 515 males and 1594 females. To select the sample, the four USAs contacted the advising units in the different colleges and identified the summer student population. Then, a representative sample at a significance level of $99 \%$ was drawn from the population. 
Ibrahim, A.

The USAs visited the classes, obtained the consent from willing students, and distributed the questionnaires with approvals from the instructors. Although the acceptable sample size is 505 participants, USAs were able to get 654 participants. Table 2 breaks down the sample according to five demographic variables.

Table 2

Sample demographic variables

\begin{tabular}{llcccccc}
\hline \multicolumn{1}{c}{ Variable } & & $\%$ & $n$ & Variable & & $\%$ & $n$ \\
\hline Gender & Male & 35.5 & 230 & College & Sciences & 52.3 & 336 \\
& Female & 64.5 & 417 & & Arts & 47.4 & 306 \\
Nationality & & & & & & & \\
& Emirati & 66.7 & 431 & Age & $17-18$ & 3.7 & 24 \\
& Arab resident & 31 & 200 & & $19-20$ & 23.4 & 151 \\
& Non-Arab Foreign & 2.3 & 15 & & $21-22$ & 48 & 310 \\
& resident & & & & $23-25$ & 23.7 & 153 \\
Accommodation & On-campus & 42 & 271 & & $26+$ & 1.2 & 8 \\
& Off-campus & 58 & 374 & & & & \\
\hline
\end{tabular}

\subsection{Limitations of the Study}

It should be noted that this study was conducted in the context of one university in the UAE and on undergraduate students. Students at this specific university mostly come from a middle class to higher class background, since the majority of them are Emirati or expat students whose families can afford them higher education. All of them are full-time students and the majority does not do any work beyond being students. Therefore, the results should not be generalized to other universities, students, or countries. Although the researcher collected data on the socio-economic status of students' families, these data were not reported in the study as they were not found significant to the level of happiness felt by students.

\section{Data analysis}

The SMLSS uses a six-point agreement format, which can be divided into three agreement and three disagreement choices. Because of the unequal number of items in each domain, the domain and total scores were made comparable by summing the item responses and dividing by the number of domain items. I started data analysis by reversing the negative statements in the questionnaire. There are 12 negative statements in the questionnaire, numbers $3,5,11,16,27,29,31,35,42,43,45$, and 55. To reverse them, I used the recode variables function in SPSS which allowed me to transform students' responses so 1 became 6, 6 became 1, etc. Then, I used descriptive statistics to calculate the means and standard deviations of the 52 questionnaire items in a descending order. By doing this, I identified sentences with the highest and lowest means. Then, I created scales for each domain in the questionnaire by summing the means of the sentences in each domain (i.e., creating cumulative means). I used descriptive statistics to analyze those scales and I did the same with the short version of the questionnaire. My aim was to identify the domains with which students perceived their highest and lowest levels of satisfaction. For the purpose of analyzing the six-item questionnaire, I used the following scale:

$\begin{array}{llll}\text { Strongly disagree } & 1.00-1.83 & \text { Mildly agree } & 3.51-4.33 \\ \text { Moderately disagree } & 1.84-2.66 & \text { Moderately agree } & 4.34-5.16 \\ \text { Mildly disagree } & 2.67-3.5 & \text { Strongly agree } & 5.17-6.00\end{array}$

Before commencement of inferential statistics, I did a normality test to check whether data were normally distributed. I investigated the numerical and visual outputs such as skewness and kurtosis z-values, Shapiro-Wilk test p-value, histograms, normal Q-Q plots and box plots. I found that the data were skewed and kurtotic and their departure from zero for most variables was beyond the acceptable span of -1.96 to +1.96 for the $\mathrm{z}$ values. I confirmed this result with visual outputs. Consequently, I used non-parametric tests such as Mann-Whiteny U and Kruskal-Wallis $\mathrm{H}$ tests. 


\section{Results}

The first and second questions investigated the extent to which students were happy along the seven life domains and which domains represented students' highest and lowest levels of satisfaction. To answer these questions, I first analyzed the short version of the questionnaire. The short version includes only one question in each domain, which asked students to rate their happiness level according to one of six choices. Table 3 summarizes students' results.

\section{Table 3}

Descriptive statistics of the short version of the questionnaire

\begin{tabular}{lccccccccc}
\hline & & & & \multicolumn{9}{c}{$\%$} & \multicolumn{1}{c}{$\%$} \\
\cline { 6 - 11 } & & Mean & SD & $\begin{array}{c}\text { Feeling } \\
\text { terrible }\end{array}$ & $\begin{array}{c}\text { Mostly } \\
\text { unhappy }\end{array}$ & $\begin{array}{c}\text { Sometimes } \\
\text { unhappy }\end{array}$ & $\begin{array}{c}\text { Sometimes } \\
\text { happy }\end{array}$ & $\begin{array}{c}\text { Mostly } \\
\text { happy }\end{array}$ & $\begin{array}{c}\text { Feeling } \\
\text { delighted }\end{array}$ \\
\hline Family life & 648 & 5.11 & 1.00 & 1.4 & 1.4 & 3.7 & 11.7 & 41.8 & 40.0 \\
Friends & 646 & 5.00 & 1.00 & 1.1 & 1.2 & 5.9 & 15.0 & 42.4 & 34.4 \\
The university & 647 & 4.06 & 1.34 & 6.3 & 6.6 & 15.8 & 30.3 & 28.0 & 13.0 \\
Yourself & 644 & 4.97 & 1.07 & 1.2 & 3.0 & 3.7 & 17.7 & 38.5 & 35.9 \\
Living & 648 & 5.02 & 1.12 & 1.9 & 2.2 & 5.1 & 15.4 & 34.4 & 41.0 \\
environment & 645 & 4.88 & 1.18 & 1.7 & 2.9 & 7.8 & 17.7 & 33.0 & 36.9 \\
Freedom & 648 & 4.69 & 1.15 & 1.9 & 3.2 & 8.2 & 24.4 & 36.0 & 26.4 \\
Future career & 649 & 5.07 & 1.01 & 1.4 & 1.8 & 2.8 & 14.5 & 41.8 & 37.8 \\
Life in general & 64.8 &
\end{tabular}

An analysis of the short version of the questionnaire shows that students were happy with their family life as it scored the highest mean at 5.11 and that the living environment came second at 5.01. The lowest level of satisfaction was for the university at a mean of 4.05, which is still in the "moderate happiness" range. Using percentages, the results show that students felt delighted about two domains: living environment and freedom they have which scored the highest at $41 \%$ and $36.9 \%$ respectively. Students were mostly happy about their family, friends, self, and future career. The only domain which reflected relatively less satisfaction was that of the university. For this domain, the prevailing response was "sometimes happy," as represented by $30.3 \%$. If all percentages for unhappiness in the university domain are added together, they account for $28.7 \%$ of students' responses.

To add more confidence to the previous results, I then analyzed the seven scales that I created for the 52 sentences in the long version of the questionnaire. Table 4 summarizes the results.

\section{Table 4}

Descriptive statistics of the seven happiness domains (long version of the questionnaire)

\begin{tabular}{|c|c|c|c|c|c|c|}
\hline & \multicolumn{2}{|c|}{$n$} & \multirow{2}{*}{ Mean } & \multirow{2}{*}{ Median } & \multirow{2}{*}{ Mode } & \multirow{2}{*}{$S D$} \\
\hline & Valid & Missing & & & & \\
\hline Family & 654 & 0 & 5.21 & 5.43 & 6.00 & .87 \\
\hline Friends & 654 & 0 & 4.93 & 5.11 & 5.44 & .82 \\
\hline University & 654 & 0 & 3.92 & 4.00 & 4.00 & .95 \\
\hline Environment & 653 & 1 & 4.40 & 4.44 & 4.00 & .84 \\
\hline Self & 654 & 0 & 5.09 & 5.29 & 5.29 & .70 \\
\hline Freedom & 654 & 0 & 4.85 & 5.00 & 5.17 & .77 \\
\hline Career & 653 & 1 & 4.82 & 5.00 & 5.33 & .83 \\
\hline
\end{tabular}

Table 4 shows that students were mostly happy with their families, as represented by a mean score of 5.20 which corresponds with "strongly agree." They were also satisfied with themselves, their friends, the freedom they have at home or university, their career prospects and their environment, with means for all these domains falling in the "moderately agree" response range. Students seem to be mildly happy with the university but not too happy, since the mean score for this domain is in the "mildly agree" response range. In addition, the median and mode are at 4.00 which is the lowest value among all of the investigated domains. 
Ibrahim, A.

As a final step, I analyzed the 52 statements in the questionnaire with an aim to identify the highest and lowest means and their corresponding domains. The results are presented in Table 5.

\section{Table 5}

Highest and lowest means and their corresponding domains

\begin{tabular}{|c|c|c|c|}
\hline Items & Domain & Mean & $S D$ \\
\hline 53. My parents treat me fairly & Family & 5.39 & 1.03 \\
\hline 10. My family is better than most & Family & 5.38 & 1.05 \\
\hline 9. I like spending time with my parents & Family & 5.33 & 1.06 \\
\hline 1. My friends are nice to me & Friends & 5.32 & 1.00 \\
\hline 4. I selected my specialization without interference/pressure from anyone & Freedom & 5.24 & 1.32 \\
\hline 23. I enjoy being at home with my family & Family & 5.24 & 1.07 \\
\hline 47. I like to try new things & Self & 5.19 & 1.07 \\
\hline 15. My friends will help me if I need it & Friends & 5.19 & 1.10 \\
\hline 24. My family gets along well together & Family & 5.18 & 1.19 \\
\hline 12. I think I am good looking & Self & 5.18 & 1.01 \\
\hline 3. I feel unhappy at the University & University & 3.28 & 1.49 \\
\hline 26. I look forward to going to University every week & University & 2.98 & 1.63 \\
\hline 11. There are many things about University I don't like & University & 2.97 & 1.52 \\
\hline 27. I wish there were different people in my neighborhood & Neighborhood & 2.87 & 1.48 \\
\hline
\end{tabular}

Overall, ten statements scored above 5.17, five of which exist in the family domain. The highest mean was for "My parents treat me well" at 5.39. Four statements scored below 3.5 which is the threshold for disagreement. Three of these statements are in the university domain and in the living environment domain. The lowest score was for "I wish there were different people in my neighborhood" at 2.87 and "There are many things about University I don't like" at 2.97.

To conclude, it is obvious that students feel delighted or quite happy over two life domains: family and self. They feel mostly happy with their friends, career, and freedom they have. Their level of happiness lags in the domains of their neighborhood and the university, and in the latter they feel sometimes unhappy.

The third research question investigated differences in the satisfaction of students based on their gender, college, residence, and nationality. A Mann-Whitney $U$ test indicated that the level of satisfaction was significantly greater for female students than for male students over the seven domains of the questionnaire (see Table 6). There were no significant differences in the satisfaction level based on whether students belonged to a sciences or literature college. There was no statistical significant differences between students who lived on campus (in the student hostel) or off campus (with their families), except for the friendship domain ( $U=45547$, $p=0.028)$. Students who lived on campus $(\mathrm{n}=342)$ were not as satisfied with their friends as students living with their families $(n=309)$ (see Table 7$)$.

Table 6

Mann-Whitney test for gender

\begin{tabular}{lcccc}
\hline & Mann-Whitney U & Wilcoxon $\mathrm{W}$ & $\mathrm{Z}$ & $\begin{array}{c}\text { Asymp. Sig. } \\
\text { (2-tailed) }\end{array}$ \\
\hline Family & 35023.00 & 61588.00 & -5.726 & .000 \\
Friends & 34381.50 & 60946.50 & -5.971 & .000 \\
University & 38860.00 & 65425.00 & -3.999 & .000 \\
Environment & 42424.00 & 68989.00 & -2.432 & .015 \\
Self & 30229.00 & 56794.00 & -7.808 & .000 \\
Freedom & 38330.00 & 64895.00 & -4.240 & .000 \\
Career & 32869.50 & 59434.50 & -6.642 & .000 \\
\hline
\end{tabular}

To investigate whether the level of student satisfaction differed based on student nationality (non-Emirati Arabs, Emiratis, or foreign students), I used Kruskal-Wallis H Test. I found significant differences among the three groups in their level of satisfaction within six domains but no statistical difference in their satisfaction with 
the university (see Table 8).

\section{Table 7}

Mann-Whitney test for accommodation

\begin{tabular}{lcccc}
\hline & Mann-Whitney U & Wilcoxon $\mathrm{W}$ & $\mathrm{Z}$ & Asymp. Sig. (2-tailed) \\
\hline Family & 49978.00 & 120103.00 & -.301 & .763 \\
Friends & 45547.00 & 115672.00 & -2.199 & .028 \\
University & 50409.50 & 120534.50 & -.115 & .909 \\
Environment & 48629.00 & 118754.00 & -.877 & .380 \\
Self & 49376.00 & 86232.00 & -.558 & .577 \\
Freedom & 49764.50 & 86620.50 & -.392 & .695 \\
Career & 49950.50 & 86806.50 & -.312 & .755 \\
\hline
\end{tabular}

Table 8

Kruskal Wallis Test for nationality

\begin{tabular}{lccc}
\hline & Chi-Square & df & Asymp. Sig. \\
\hline Family & 10.164 & 2 & .006 \\
Friends & 7.560 & 2 & .023 \\
University & 1.248 & 2 & .536 \\
Environment & 23.842 & 2 & .000 \\
Self & 6.102 & 2 & .047 \\
Freedom & 16.517 & 2 & .000 \\
Career & 29.849 & 2 & .000 \\
\hline
\end{tabular}

Pairwise comparisons indicate that Emirati students were more satisfied than non-Emirati Arab students over five domains: family, self, neighborhood, freedom they have, and career prospects (see Table 9).

\section{Table 9}

Mann-Whitney U test for nationality

\begin{tabular}{lcccc}
\hline & Mann-Whitney U & Wilcoxon $\mathrm{W}$ & $\mathrm{Z}$ & Asymp. Sig. (2-tailed) \\
\hline Self & 38176.00 & 58276.00 & -2.317 & .021 \\
Family & 36385.50 & 56485.50 & -3.175 & .001 \\
Friends & 39262.00 & 59362.00 & -1.803 & .071 \\
University & 41922.50 & 135018.50 & -.553 & .580 \\
Environment & 32856.00 & 52956.00 & -4.811 & .000 \\
Freedom & 34675.50 & 54775.50 & -3.964 & .000 \\
Career & 31639.00 & 51739.00 & -5.390 & .000 \\
\hline
\end{tabular}

\section{Discussion}

The UAE has three federally funded universities and many other private universities and colleges. Admission to federal universities is open to all Emirati students, but very competitive for non-Emirati students, who can apply for two universities only: Zayed University and UAE University. Emirati students make up the majority of the student populations at the federal universities. At the university where the study was conducted, students are provided free education at the BA or BSC level, and Emirati students who come from distant cities in the UAE are provided room and board. The university buses pick up these students from their homes on Saturdays and drop them off on Thursdays.

This study has some major results. The lowest level of satisfaction among students was for the university. Mean scores for sentences such as "I look forward to going to University every week" and "There are many things about University I don't like" come at 2.97 and 2.98 out of 6 respectively. Satisfaction with the university was significantly greater for female students than for male students over the seven domains of the questionnaire. Students who lived on campus were not as satisfied with their friends as the group living with their families. 
Ibrahim, A.

Emirati students show more satisfaction than non-Emirati Arab students over five domains: family, self, neighborhood, freedom they have, and future career security.

In order to provide interpretations for these results, I asked the four USAs to write reflections on the results and they willingly agreed. I advised them to be objective and fair in what they write and not to jump to conclusions based on one single incident or experience. Those reflections are the basis for the discussion that follows. The four USAs have given consent for the publication of their answers and comments on the main results of the study. As I will be using quotations, pseudonyms are used in reporting these comments.

With regard to the first result, the USAs provided different interpretations for the relatively low level of student happiness with the university that was reported. David, a mass communication student, viewed it as a result of "the heavy assignments and projects in the courses." He noted, students might have "had preconception[s] that university simply means sitting in a large room with a lot of students listening to one professor speaking for hours." Another reason he provided was "lack of interesting and entertaining facilities on campus to motivate students to look forward to university." A third reason was the fact that in over $90 \%$ of the courses offered, English - a second language to the majority of the students - is used as the language of instruction. Finally, for David, "many students believe that segregated education [where males and females are taught in separate campuses] makes university life boring and dull." Diane, a translation studies student, provided other reasons to explain students' dissatisfaction with the university. She stated, "the terms and conditions of being part of the university, the strictness of rules that the students should follow every day, the stress of exams and quizzes, the difficulties of dealing with some doctors who sometimes you are forced to take courses with, and the things you give up, such as family gatherings, trips and friends, in order to do well as a student and to enhance your performance in your major" are reasons for the dissatisfaction with the university. These reasons were also felt by Heather, a chemical and petrol engineering student. She explained, "The heavy curriculum and overload, weekly quizzes, and the high dependence of grades on the exams rather than projects" were reasons for unhappiness with the university.

As to why female students are happier than male students, David argued that "female students have a lot of facilities at their disposal, both on campus and in their hostels." The fact that the female student population is larger than the male student population made "the chance of making friends higher for females." The girls also "have many more activities on campus that are fun and interesting." Diane viewed the lower level of satisfaction among male students in light of the responsibilities the male students had, suggesting that, "male students tend to stress themselves more during their studies in order to have a career that might make them more independent from their families." For female students, she alluded to societal norms and culture, stating that "this is less stressful [for females] because female students are provided with better life conditions by their families and community." In the UAE as well as in Arab and Islamic societies overall, men are supposed to provide for their families. They are the primary "bread winners" and women can choose not to work in a profession, even if they are educated. Heather provided one explanation to the greater happiness felt by female students based on the freedom ascribed to males more than females: "Although male students have more freedom than females, they aren't able to achieve what they want, which makes them less satisfied than females who may be able to achieve what they want even if they have less freedom." The traditions in the Arab and Islamic societies provided more protection for females by not allowing them to move freely like males. Therefore, a female student with limited freedoms finds herself mostly at home, living in a somewhat secured enclosure with more time to devote to study.

With regard to why students who live with their families are happier, David believed, "there is nothing in this world that would mean more to anyone than family." It seemed that college students who lived with their families had privileges over those who lived in the hostels, as the hostels were governed by certain rules and regulations which make life at home more interesting. David explained, "It is certainly a privilege that some students have families that look after them, provide them with fresh homemade food, and give them shelter to call home." Ethan, an environmental biology student, looked at this issue in terms of the new responsibilities that 
The happiness of undergraduate students at one university in the United Arab Emirates

on-campus students had that made them less satisfied than their counterparts who lived with their families. "Maybe because it is a different experience in that they have to be more independent and do their own laundry and chores ... and they are just not used to that." Food was mentioned as one important factor that might be causing unhappiness. "Living in the dorm means you eat the food provided in the dorms, which can be restricting and unpleasant; a student cannot request special dishes and has to eat what is given that day rather that asking his mother to make his favorite meal." Diane believed that "some students might be happier being far from their families if they have less freedom at home, but the fact that many were not happy on campus could mean that their families were playing a role in keeping them attached to home, and less independent." The results of the study confirm that campus life set boundaries and rules that could make students less comfortable. In other words, even though students were far from their parents which, on its face, suggests that they would have more freedoms on campus, in reality, the university rules and protocols of campus life did not make students any happier. Heather explained that, "Students who live at home can most likely meet their old friends, while students who live on campus have limited chances as their new friends come from the university only. In case they have friends in their own cities, they can meet them only during the weekend when they are back home."

As for the reasons why Emirati students are happier than Arab expat students, David reasoned that "Emirati students come from rich and financially stable families." Moreover, due to the wise leadership of the UAE, "an Emirati student hardly needs to worry or stress about their future, because he/she is guaranteed a job with a reasonable salary and a home." The UAE provides citizens with secure employment opportunities and supports them in marriage and other life domains. "Career opportunities are less of a concern for Emirati students, thanks to Emiratization." Emiratization is a government policy to place national citizens in positions that historically were occupied by expatriates. In addition, David went on, "with more cash in their pockets, it becomes very easy for Emirati students to spend more on entertainment and leisure activities." Ethan had the same viewpoint. "I see absolutely no reason why any local student would be unhappy, since they are privileged and literally given everything. Whether it is in university or at home, most local students have everything easy for them." He related the following scenario to illustrate his claim:

The moment they graduate from high school, they have a brand new car waiting for them. They get accepted to any college including IT and medicine (which is not available for expats). They need to get a much lower average to get accepted in the university than expats. In addition, expats have more screening processes and placement exams which local students do not have to take. Moreover, for non-local students reaching their senior year, we begin to notice that most training opportunities, scholarships, and work opportunities are for locals, and if not, the requirements are very high and so the competition is even higher.

Diane agreed that the higher level of satisfaction on the part of local students can be explained by the "economic conditions." Emirati students tend to have "higher economic conditions than the other students, which leads to greater freedom, especially in areas such as spending money and future career security. Finally, Heather referred to the "level of confidence" that Emirati students enjoy which is apparently not available to non-citizen students who are always conscious of the fact that "they are residents" and their families could leave or be asked to leave at any time.

\section{Conclusions and implications}

The purpose of this study was to examine the status of college students' happiness within seven life domains; self, educational institution, family, friends, living environment, freedom, and future financial security. The results of this study are consistent with previous research, which supported the importance of self-image, academic success and financial security as predictors of the happiness of college students (Cheng \& Furnham, 2002; Flynn \& McLeod, 2015). Similar to the findings in Chow (2005), the results of this study confirm that college students are extremely satisfied with their lives and especially in their relationships with parents, living 
Ibrahim, A.

environment, and close friends.

The finding of the current study that financial security is a significant determinant of happiness is not surprising. This result is consistent with previous studies finding future employment opportunities and financial burdens to be high stress triggers in the lives of college students (Guo, Wang, \& Johnson, 2011). As found in previous studies, female students in this study were also found to be happier than male students. Although this might be the result of facilities they enjoy on their campus, previous research also highlights their superior friend-making skills (Cheng \& Furnham, 2002).

Given the importance of being happy both at individual and societal levels, it follows that the Ministry of Happiness in collaboration with educational institutions of pre- and post-secondary education in the UAE should develop interventions to increase individual happiness of students in all levels of education. This study is possibly the first to be conducted on happiness in the UAE and thus it sets the foundation for more research to be conducted on this issue. Given that an institution of higher learning has received the unhappiest rating in this study, educational decision makers should investigate in more detail how to make the learning environment more enjoyable to students. Equally important are studies that focus on stress and future financial stability for the graduates. Qualitative research should be conducted to understand the perceptions of different student populations in multicultural educational institutions. Finally, studies on happiness of high school students are needed because that is an important stage in their preparation for future educational and career choices.

Acknowledgements: This research was funded by the United Arab Emirates University with fund number 31D067-SURE 2016 (2).

\section{References}

Astin, A. W. (1997). What matters in college: Four critical years revisited. Jossey-Bass.

Cheng, H., \& Furnham, A. (2002). Personality, peer relations, and self-confidence as predictors of happiness and loneliness. Journal of Adolescence, 25(3), 327-339. https://doi.org/10.1006/jado.2002.0475

Chow, H. P. (2005). Life satisfaction among university students in a Canadian Prairie City: A multivariate analysis. Social Indicators Research, 70(2), 139-150. https://doi.org/10.1007/s11205-004-7526-0

Cummins, R. A., Lau, A. A., Mellor, D., \& Stokes, M. A. (2008). Encouraging governments to enhance the happiness of their nation: Step 1: Understand subjective wellbeing. Social Indicators Research, 91(1), 23-36. https://doi.org/10.1007/s11205-008-9324-6

Dean, A., \& Gibbs, P. (2015). Student satisfaction or happiness? Quality assurance in education, 23(1), 5-19. https://doi.org/10.1108/QAE-10-2013-0044

Diener, E. (1994). Assessing subjective well-being: Progress and opportunities. Social Indicators Research, 31, 103-157. https://doi.org/10.1007/BF01207052

Flynn, D. M., \& MacLeod, S. (2015). Determinants of happiness in undergraduate university students. College Student Journal, 49(3), 452-460.

Guo, Y.-J., Wang, S.-C., \& Johnson, V. (2011). College student's stress under current economic downturn. College Student Journal, 45, 536-543.

Huebner, E. S. (1994). Manual for the multidimensional life satisfaction scale. Retrieved from https://ww2.cas.sc.edu/psyc/sites/default/files/directory_files/huebslssmanual_0.pdf

Kashdan, T. B. (2004). The assessment of subjective well-being (issues raised by the Oxford Happiness Questionnaire). Personality and Individual Differences, 36(5), 1225-1232. https://doi.org/10.1016/S0191-8869(03)00213-7

Khaishgi, A. E. (2016, March 20). 'Happiness is a serious job’: UAE's Minister of Happiness embraces new role. The National. Retrieved from http://www.thenational.ae/uae/government/happiness-is-a-serious-job-uaes-minister-of-happiness-embr aces-new-role 
The happiness of undergraduate students at one university in the United Arab Emirates

Lykken, D. T. (1999). Happiness: what studies on twins show us about nature, nurture and the happiness set-point. New York: Golden Books.

Lyubomirsky, S., Sheldon, K. M., \& Schkade, D. (2005). Pursuing happiness: the architecture for sustainable change. Review of General Psychology, 9, 111-113. https://doi.org/10.1037/1089-2680.9.2.111

Michalos, A. C. (2008). Education, happiness and wellbeing. Social Indicators Research, 87, 347-366. https://doi.org/10.1007/s11205-007-9144-0

Norrish, J. M., \& Vella-Brodrick, D. A. (2007). Is the study of happiness a worthy scientific pursuit? Social Indicators Research, 87(3), 393-407. https://doi.org/10.1007/s11205-007-9147-X

Ross, S. E. (1999). Sources of stress among college students. College Student Journal, 33(2), 312-317.

United Arab Emirates. (2010). UAE Vision 2021. Retrieved from https://www.vision2021.ae/en 
Ibrahim, A. 